\title{
INHIBITION OF CARCINOGENESIS BY SEED AND SOYBEAN MEAL EXTRACT IN COLON OF MICE: APOPTOSIS AND DYSPLASIA
}

\author{
ANINDINI WINDA AMALIA ${ }^{1}$, KUSMARDI $^{2}$, BERNA ELYA ${ }^{1}$, ADE ARSIANTI $^{3 *}$ \\ ${ }^{1}$ Department of Phytochemistry and Pharmacognosy, Laboratory of Phytochemistry and Pharmacognosy, Faculty of Pharmacy, Universitas \\ Indonesia, Indonesia. ${ }^{2}$ Department of Anatomical Pathology, Faculty of Medicine, Universitas Indonesia, Indonesia. ${ }^{3}$ Department of \\ Medical Chemistry, Faculty of Medicine, Universitas Indonesia, Indonesia. Email: arsi_ade2002@yahoo.com
}

Received: 22 November 2016, Revised and Accepted: 30 December 2016

ABSTRACT

Objective: Colon cancer is a major public health problem. Soybean has demonstrated chemopreventive and anticancer. Here, we have investigated the effect of a standardized seed and soybean meal extract (SE) with content of lunasin, here named grobogan extract (GE) and SE. They are botanical drug substance in experimental models of colon cancer in vivo.

Methods: The effect of GE and SE was examined on the preneoplastic lesions (aberrant crypt foci), polyps and tumors induced by the carcinogenic agent azoxymethane $(10 \mathrm{mg} / \mathrm{kg})$ and dextran sodium sulfate $2 \%$ as well as in a xenograft model of colon cancer in mice.

Results: GE and SE increased apoptosis (p=0.001). GE (150 mg/kg) has the highest impact level of apoptosis (p=0.009). GE and SE decreased dysplasia $(\mathrm{p}=0.024)$. GE (200 mg/kg) has the highest impact level of dysplasia ( $p=0.002)$, and SE (200 mg/kg) has the second impact level of dysplasia ( $\mathrm{p}=0.003)$.

Conclusions: GE and SE inhibition of colon carcinogenesis with increased level of apoptosis and decrease level of dysplasia.

Keywords: Soybean, Lunasin, Colon cancer, Azoxymethane, Dextran sodium sulfate, Apoptosis, Dysplasia.

(C) 2017 The Authors. Published by Innovare Academic Sciences Pvt Ltd. This is an open access article under the CC BY license (http://creativecommons. org/licenses/by/4. 0/) DOI: http://dx.doi.org/10.22159/ajpcr.2017.v10i4.16276

\section{INTRODUCTION}

Colorectal cancer (CRC) represents the third most common cancer in men $(746,000$ cases, $10 \%$ of the total) and the second in women (614,00 cases, $9.1 \%$ of the total) worldwide [1]. Almost 55\% CRC occur in more developed country but it is inevitable this time the incidence of CRC increased in developing country. It is happened because of change in diet and lifestyle, among other: Increased consumption of red meat and processed foods, decreased consumption of foods containing fiber (fruits and vegetables), increased weight (obesity), low physical activity, smoking and high alcohol intake [1,2].

Pharmacoeconomic studies have highlighted a trend for rising cost associated with CRC, which is linked to the increasing use of targeted biological therapies [3]. Screening strategies are utilized but have not reduced disease incidence or mortality [4]. Furthermore, therapeutic intervention, which is by itself very toxic, may fail to prevent disease progression to metastatic disease [5]. Therefore, there is an interest in both cancer preventive strategies - which include experimentation with safe phytochemical agents - and new curative treatments [6].

Soybean (Glycine max) is an ancient legume consumed worldwide, but most commonly in Asian countries, such as China, Japan, Korea, Taiwan, and Indonesia. The demographic consumption pattern of soybean varies geographically with Asians utilizing (20-80 g/day), mostly in the forms of traditional soy foods and fermented soy foods, such as soybean, soy milk, tofu, tempeh, misso, natto, soybean paste, and soy sauce $[7,8]$ as compared to Western population consuming meagerly (1-3 g/day), mostly in processed forms, such as soy drinks, breakfast cereals, energy bar and soy burger [9].

Epidemiological evidence has demonstrated an association between the consumption of soybean and improved health, particularly as a reduced risk for cardiovascular diseases [10] and cancer, such as breast, prostate, endometrial, lung, and bladder cancer [11-17]. Moreover, a number of animal models support anticancer properties of soy which constituents have been shown to suppress tumor growth in a variety of tissues including skin, bladder, mammary, and prostate [18]. In last decades, studies have isolated and identified an array of biologically active compounds or phytochemicals contained in soybean with cancer preventive effects.

A likely candidate is lunasin, a novel cancer preventive peptide, the efficacy of which has been demonstrated in our laboratory [19-22]. Initially identified in soy, lunasin is also present in barley, a food crop known for its health effects [21]. Lunasin is a unique 43 amino acid soybean peptide that contains at its carboxyl end 9 Asp (D) residues, an Arg-Gly-Asp (RGD) cell adhesion motif, and a predicted helix with structural homology to a conserved region of chromatin-binding proteins. It has been shown to suppress carcinogenesis caused by chemical carcinogens and oncogenes in in vitro models and a mouse model for skin cancer [19-22].

Histone acetylation and deacetylation have been associated with eukaryotic transcriptional regulatory mechanisms [23]. The affinity of lunasin for hypoacetylated chromatin suggests a role in chromatin modification, a process implicated in cell cycle control and in the role of tumor suppressors in carcinogenesis [24]. Transfection of the lunasin gene into mammalian cells leads to mitotic arrest and cell lysis, resulting in lunasin bound to the chromatin [25]. Subsequently, we showed that exogenous addition of synthetic lunasin peptide to mammalian cells inhibits histone acetylation in the presence of sodium butyrate, a histone deacetylase inhibitor [22]. Because lunasin inhibits core $\mathrm{H} 3$ and $\mathrm{H} 4$ histone acetylationin mammalian cells [22], we propose an epigenetic mechanism whereby lunasin selectively kills cells that are being transformed or newly transformed cells by disrupting the dynamics of histone acetylation-deacetylation, which is triggered by the inactivation of tumor suppressors that operate through histone acetylation deacetylation [19]. 
In this paper, we used the inhibition of carcinogenesis by lunasin as a bioactivity assay for the first time. These were measured in lunasin extracted from a number of Indonesian soybean varieties and soybean meal through oral administration to measure apoptosis and dysplasia.

\section{METHODS}

Plant material and extranction

Soybean is obtained from Indonesian Legumes and Tuber Crops Research Institute Malang of East Java, Indonesia. Soybean varieties were used in this study is Grobogan because its content highest protein than other varieties (to reach $43.9 \%$ ). Soybean meal is obtained from local market in Semarang of Central Java, Indonesia.

Before extraction, samples of soybean Grobogan pressed, to separate oil. The residue obtained from pressing process is made of powder with blender. The procedures for maceration were in accordance with previous studies [26,27]. The residue of grobogan seed and soybean meal are macerated with phosphate buffer saline solvent $(1: 5$, 60 minutes) and filtrated twice. Filtrate of grobogan and soybean meal be dried with rotary vapor and kept temperature below $60^{\circ} \mathrm{C}$. The result was tested by high performance liquid chromatography to determine the content of lunasin.

\section{Animal}

Male Swiss-Webster mice ( 12 weeks old) of \pm 20 g body weight, supplied by Agency for Health Research and Development Ministry of Health of the Republic of Indonesia. The mice were maintained under standard laboratory conditions housed in independent ventilation cages (with stainless steel grill top, $48 \mathrm{~cm} \times 35 \mathrm{~cm} \times 20 \mathrm{~cm}$ ) under hygienic and under controlled humidity conditions $(55 \% \pm 5 \%)$, light $(12 \mathrm{hrs} / 12 \mathrm{hrs}$ light/dark cycle), and temperature $\left(23 \pm 1^{\circ} \mathrm{C}\right)$. The mice were allowed free access to food and water. The animals were carefully examined for 1 week prior to use in the experiments, and only healthy animals were chosen. All protocols and surgical procedures were approved by the Institute of Animal Care and Use Committees of Medical Faculty University of Indonesia.

\section{Induction of colon cancer}

Induction of colon carcinogenesis adopted Kusmardi et al.: Mice induced with azoxymethane (AOM) were dissolved in $0.9 \% \mathrm{NaCl}$ at a dose of $10 \mathrm{mg} / \mathrm{kg}$ body weight by intraperitoneal (i.p.) injection early as one. 1 week after induction of AOM, mice given standard feed and water containing dextran sodium sulfate (DSS) $2 \%$ daily for 1 week [28].

\section{Experimental groups}

Mice were randomized into nine experimental groups as follows: Normal group, mice oral administration of physiological saline for 4 weeks, without a single i.p. injection AOM and DSS; negative group, mice oral administration of physiological saline for 4 weeks, and received a single i.p. injection AOM and DSS; positive group, mice oral administration of aspirin $(150 \mathrm{mg} / \mathrm{kg})$ for 4 weeks, and received a single i.p. injection AOM and DSS; grobogan treatment group, mice oral administration of grobogan extract (GE) $(75,150,200 \mathrm{mg} / \mathrm{kg}$, respectively) for 4 weeks, and received a single i.p. injection AOM and DSS; soybean meal treatment group, mice oral administration of soybean meal extract (SE) $(75,150,200 \mathrm{mg} / \mathrm{kg}$, respectively) for 4 weeks, and received a single i.p. injection AOM and DSS. After 4 weeks treatment, mice of each group were sacrificed to know inhibition of colon carcinogenesis.

\section{Hematoxylin eosin staining}

A piece of colorectal tissue made paraffin blocks. Paraffin blocks made $4 \mu \mathrm{m}$ thick slices and mounted on glass objects for HE staining stages as follows: Deparaffinizesection using xylol I, II and III, respectively 5 minutes. Then re-hydrated using absolute alcohol, $96 \%$ and $70 \%$ respectively for 5 minutes, and washed in running water for 5 minutes. The preparation inserted into hematoxylin (Meyer solution) for 7 minutes and rinsed in running water for 10 minutes. After that, the stocks dipped into a saturated lithium carbonate 1-2 minutes and rinsed with running water for 5 minutes.
Preparations controlled if the blue color is sufficient, if it is not put back into solution Meyer (hematoxylin) for 2 minutes, then rinsed in running water, soaked in eosin for 1-2 minutes, dehydrated in alcohol absolute $70 \%, 80 \%, 96 \%$ respectively for 3 minutes, clearing with xylol I - II - III, and the last drops with entelan and covered with a glass lid. Preparations viewed using a light microscope with $\times 400$ magnification. Histological assessment was done in a blinded fashion to avoid bias. Based on H\&E staining, histological alterations, such as mucosal ulceration, dysplasia, and carcinoma, were verified by a board-certified pathologist. Carcinoma was defined as a high-grade dysplasia of the colonic mucosa that had invaded beyond the muscularis mucosa and into the submucosa.

\section{Immunohistochemistry}

For cleaved-caspase 3 immuno-histochemistry analysis, colorectal tissue deriving from mice were fixed in buffered formalin, embedded in paraffin, and cut into $4 \mu \mathrm{m}$-thick serial sections. Sections were stained with the cleaved-caspase $3(1: 100 \mathrm{v} / \mathrm{v})$ antibodies. After three 5 -minute washes, the secondary antibody was added and the samples were incubated at room temperature for $20 \mathrm{~min}$. The streptavidinHRP detection system was added and samples were incubated at room temperature. After three 5-minute washes, $50 \mathrm{ml}$ of chromogen was added and the reaction stopped after $1 \mathrm{~min}$ in water. Histological analysis colorectal tissues were fixed in $10 \%$ formalin. Thin $(0.5 \mathrm{~mm})$ paraffined section were prepared and stained with toluidine blue as and then processed for light microscopy with $\times 400$ magnification.

\section{Statistical analysis}

All data are presented in mean \pm standard deviation. Differences in levels among treatment groups were analyzed by ANOVA using SPSS 20.0 statistical package. A p $<0.05$ was considered significant statistically.

\section{RESULTS}

Weight body index group of mice with GE and SE is displayed in Table 1.

In grobogan group shows GE $(150 \mathrm{mg} / \mathrm{kg}$ ) has the highest weight body index, compared with other weight body index in grobogan treatment group. Weight body index of GE $(150 \mathrm{mg} / \mathrm{kg})$ has higer than weight body index of aspirin (control positive). In soybean meal group shows SE $(150 \mathrm{mg} / \mathrm{kg})$ has the highest weight body index, compared with other weight body index in soybean meal treatment group. Weight body index of SE $(150 \mathrm{mg} / \mathrm{kg})$ has higer than weight body index of aspirin (control positive)

\section{DISCUSSION}

Effect of giving seed and SE for weight body index as shown in Table 1. This Table 1 shows that weight body index of mice in all of the group treatment at weekly is above 1 , which means that seed and SE contribute to weight gain in mice.

Soybean seeds contain to $40 \%$ of crude protein and about $20 \%$ of fat, and soybean meal characterized higher content of crude protein about

Table 1: Weight body index group of mice with GE and SE

\begin{tabular}{lllllll}
\hline \multirow{2}{*}{ Group } & \multicolumn{2}{l}{ Weeks } & & & & \\
\cline { 2 - 7 } & $\mathbf{1}$ & $\mathbf{2}$ & $\mathbf{3}$ & $\mathbf{4}$ & $\mathbf{5}$ & $\mathbf{6}$ \\
\hline Normal & 1.11 & 1.18 & 1.20 & 1.18 & 1.17 & 1.23 \\
Negative & 1.12 & 1.23 & 1.25 & 1.28 & 1.30 & 1.41 \\
Positive (aspirin) & 1.13 & 1.21 & 1.24 & 1.22 & 1.18 & 1.23 \\
GE (75 mg/kg) & 1.08 & 1.19 & 1.19 & 1.21 & 1.20 & 1.21 \\
GE (150 mg/kg) & 1.10 & 1.21 & 1.24 & 1.28 & 1.27 & 1.32 \\
GE (200 mg/kg) & 1.09 & 1.17 & 1.26 & 1.19 & 1.16 & 1.22 \\
SE (75 mg/kg) & 1.09 & 1.18 & 1.20 & 1.21 & 1.19 & 1.20 \\
SE (150 mg/kg) & 1.08 & 1.19 & 1.18 & 1.21 & 1.19 & 1.25 \\
SE (200 mg/kg) & 1.04 & 1.08 & 1.07 & 1.05 & 1.05 & 1.08 \\
\hline
\end{tabular}

GE: Grobogan extract, SE: Soybean meal extract 
40-49\%. Protein of soybean products characterized much quantity of arginine, cystine, histidine, isoleucin, leucine, lysine, methionine, phenylalanine, theonine, tryptophan and valine [29].

Soybean contains isoflavones. These compounds have got biochemical activity, including treatment of chronic diseases. Studies in humans and animals have shown that the consumption of soybean or soybeanderived products may help to protect against cardiovascular diseases, certain types of cancer, obesity, and diabetes [30]. The ability of isoflavones to prevent these diseases depends on their absorption, metabolism, distribution to target tissues and excretion of waste compounds, that is, their bioavailability. In other study showed that a diet containing soy isoflavones increased the body weight and fat percentage, also the serum concentrations of insulin-like growth factor-I (IGF-I) and interleukin-6 were increased by high levels of soy isoflavones [31].

Our results indicate that seed and SE provide protection against colon carcinogenesis in male AOM-induced Swiss Webster mice, specifically against earlier stages of colon carcinogenesis. This is evidenced by the higher incidence of apoptosis (Figs. 3 and 5) and the lower incidence of dysplasia (Figs. 4 and 6). In Fig. 3, with ANOVA analysis shows that $\mathrm{GE}$ and SE increased apoptosis ( $\mathrm{p}=0.001)$. GE $(150 \mathrm{mg} / \mathrm{kg})$ has the highest impact level of apoptosis $(\mathrm{p}=0.009)$. In Fig. 5 , it shows that immunohistochemistry to active caspase-3 for apoptosis detection. This figure shows that GE $(150 \mathrm{mg} / \mathrm{kg})$ has a same impact level of apoptosis with control positive. In this research, we use aspirin for control positive. Long-term aspirin use reduces the risk of colon cancer [32]. Mechanisms of aspirin for chemoprevention include inhibition of the
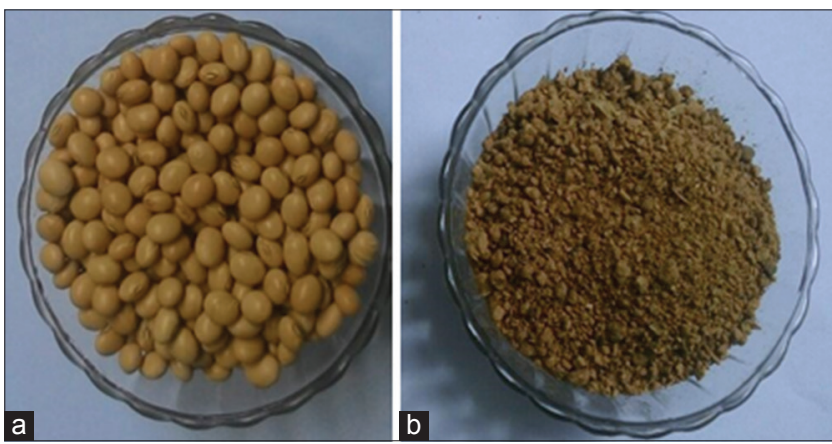

Fig. 1: (a and b) Soybean varietas Grobogan (left), soybean meal (right)

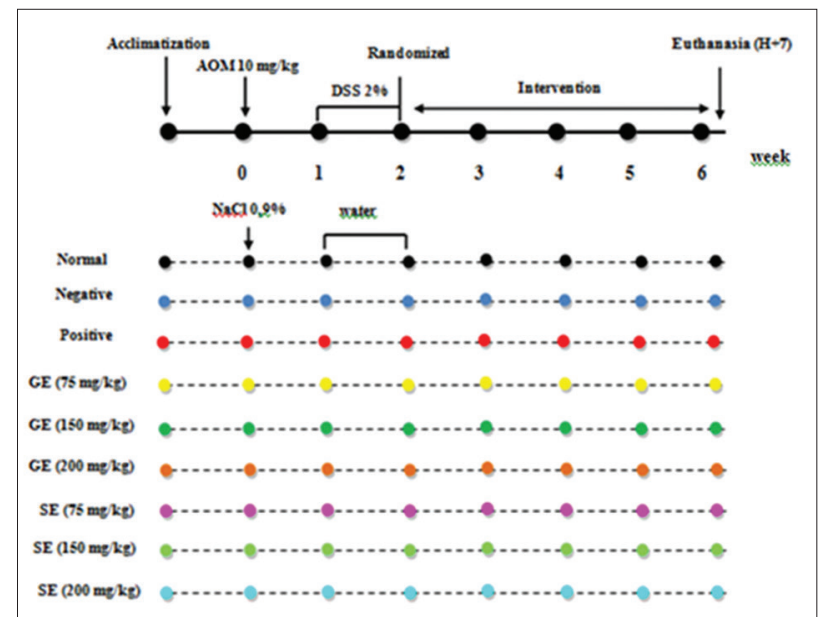

Fig. 2: Experimental protocol for colon carcinogenesis model. Normal (without induced AOM and DSS), Negative (induced AOM and DSS without intervention), Positive (control with aspirin), GE : Grobogan extract, SE: Soybean Meal extract. cyclooxygenase (COX) pathway, or COX-independent mechanisms, for example, the PIK3CA pathway, or therapy-induced senescence of cancer cells [33].

In other study, it shows that the combination of etoricoxib and atorvastin against DMH-induced colon cancer by increasing the level of antioxidant enzymes. The histopathological this study demonstrated that the combination treatment showed more positive effect in the prevention of colon carcinogenesis by reducing the inflammation, hyperplastic, dysplastic change in colon crypt cells [34]. Etoricoxib specifically binds to and inhibits the enzyme COX-2, resulting in inhibition of the conversion of arachidonic acid into prostaglandins. Inhibition of COX-2 may induce apoptosis and inhibit tumor cell proliferation and angiogenesis [35]. In this study used aspirin, it has same mechanism with etoricoxib. Aspirin exhibit increase level of apoptosis and decrease level of dysplasia in colon crypt cell (Figs. 3 and 4). Apoptosis and dysplasia are indication of carcinogenesis of colon cancer. In this study, adopt colitis-associated colon cancer. AOM and DSS can make chronic inflammatory process may contribute to multistep colon carcinogenesis in the inflamated colon. They include overproduction of reactive oxygen and nitrogen species, overproduction and upregulation of productions and enzymes of arachidonic acid biosynthesis pathway and cytokines, and intestinal immune system dysfunction [36]. Aspirin's most wellcharacterized pharmacologic activity is the permanent modification of the prostaglandin endoperoxide synthetase or COX enzymes. These enzymes are rate limiting for the conversion of arachidonic acid to prostaglandins and related eicosanoids. COX-1 isoenzyme is constitutively expressed in most tissues, whereas growth factors, oncogenes, tumor promoters, and inflammatory cytokines induce the COX-2 isoenzyme [37]. Treatment with aspirin for colitis-associated

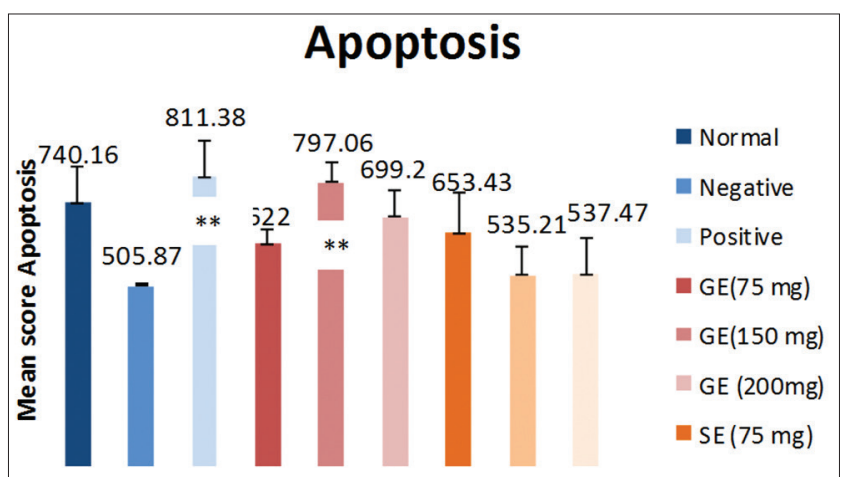

Fig. 3: Mean score apoptosis of mice with grobogan extract and soybean meal extract $(p=0,001) .{ }^{*} p<0.05$ compared to control negative group, ${ }^{* *} \mathrm{p}<0.01$ compared to control negative group

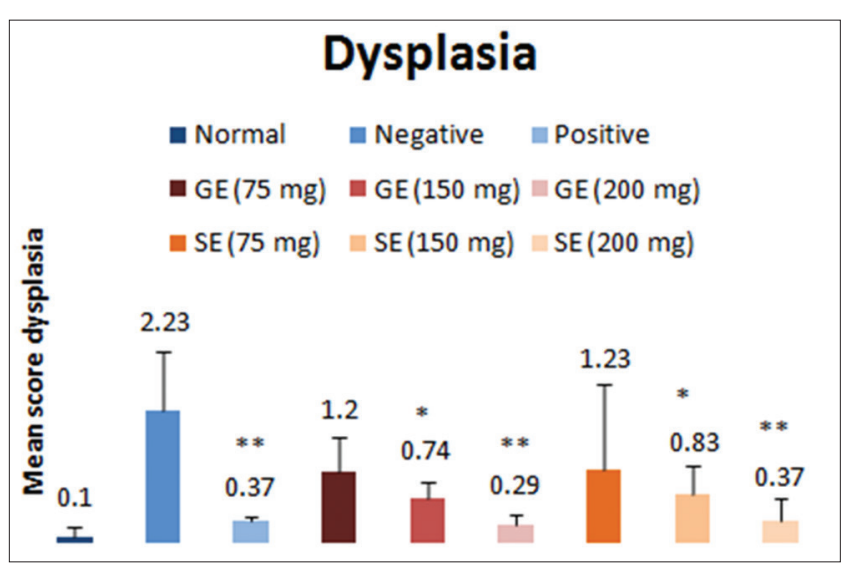

Fig. 4: Mean score dysplasia of mice with grobogan extract and soybean meal extract $(p=0,024), * p<0.05$ compared to control negative group, ${ }^{* *} \mathrm{p}<0.01$ compared to control negative group 


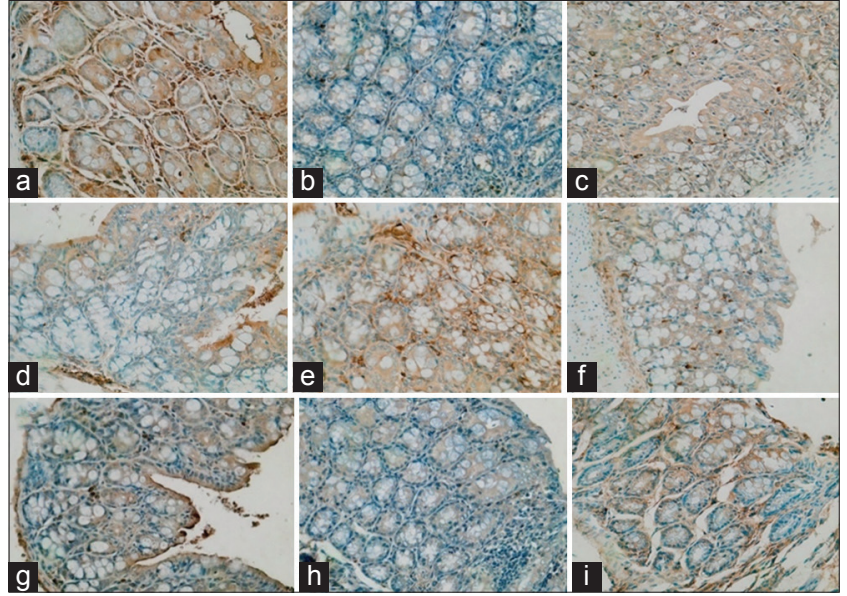

Fig. 5: Grobogan extract (GE) and soybean meal extract (SE) increase expression of caspase3. Relative amounts of caspase 3 were quantified using the Image J software. The values are expressed as the mean $\pm S D, p<0,05$; (a) Normal group, (b) negative group, (c) positive group, (d) GE $75 \mathrm{mg} / \mathrm{kg}$ ), (e) GE $150 \mathrm{mg} / \mathrm{kg}$, (f) GE $200 \mathrm{mg} / \mathrm{kg}$, (g) SE $75 \mathrm{mg} / \mathrm{kg}$, (h) $S E 150 \mathrm{mg} / \mathrm{kg}$, (i) $S E 200 \mathrm{mg} / \mathrm{kg}$ ), (magnification $\times 400$ )

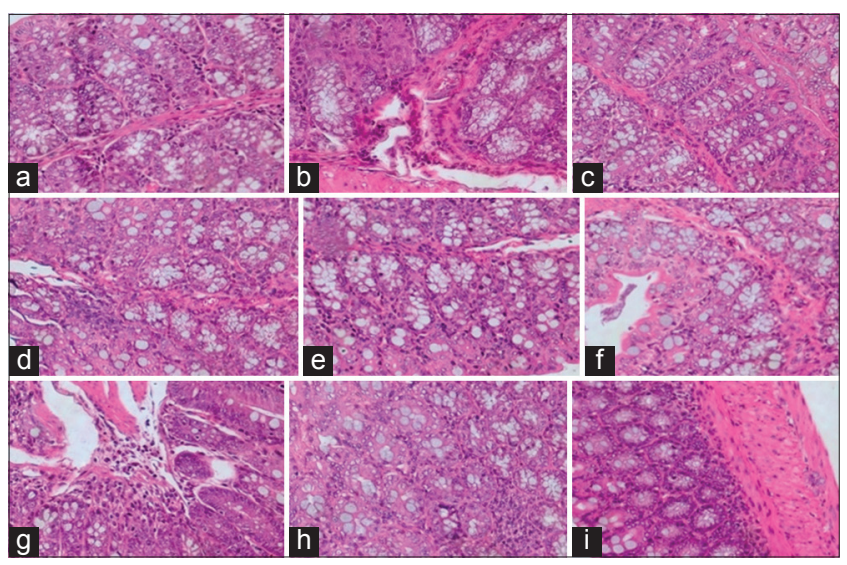

Fig. 6: Grobogan extract (GE) and soybean meal extract (SE) decrease dysplasia. Relative amounts of dysplasia were quantified using the Image $J$ software. The values are expressed as the mean \pm standard deviation, $\mathrm{p}<0.05$; (a) normal group,

(b) negative group, (c) positive group, (d) GE $75 \mathrm{mg} / \mathrm{kg}$, (e) GE $150 \mathrm{mg} / \mathrm{kg}$, (f) GE $200 \mathrm{mg} / \mathrm{kg}$, (g) SE $75 \mathrm{mg} / \mathrm{kg}$, (h) $S E 150 \mathrm{mg} / \mathrm{kg}$, (i) $S E 200 \mathrm{mg} / \mathrm{kg}$, (magnification $\times 400)$

colon cancer in this study assumed that inhibiting inflammatory process can prevent colon carcinogenesis.

Soybeans are known a low-risk food for cancer, and correlation between the intake of soybean foods and the morbidity of cancer [38]. Dietary agents known used natural inhibitors of insulin-like growth factor-1 receptor (IGF-1R) for the management of tumors. IGF-1R is a member of the receptor tyrosine kinase superfamily the ligand binding leads to receptor activation and phosphorylation of downstream substrates. Signaling through IGF-1R in normal cells leads to the activation of multiple intracellular pathways, mediated by the receptor associated tyrosine kinase domain, PI-3 kinase, and by serine/threonine kinase (Akt), yielding growth and enhanced survival. In cancer cells, IGF-1R plays an even more critical role because it contributes to the promotion of tumor growth by inhibition of the apoptosis, transformation, metastasis, and induction of angiogenesis through the vascular endothelial growth factor [39]. Soybean downregulated a set of genes that are necessary for the angiogenesis pathway in LNCaP, PC-3, and DU-145 PCa cells. These genes included platelet-derived endothelial cell growth factor 1, fibroblast growth factor 1 (FGF1), IGF1, FGF receptor 3 (FGFR3), interlukin-1 $\beta$ (IL-1 $\beta$ ), IL-6, IL-8, platelet/endothelial cell adhesion molecule (CD31 antigen or PECAM1), CXCL10, and many other molecules that are essential to angiogenesis [40]. That study shown that soybean can prevent colon carcinogenesis by inhibition of IGF-1R.

Lunasin in soybean acts as a surrogate tumor suppressor that tightly binds to deacetylated core histones disrupting the balance between acetylation-deacetylation, which is perceived by the cell as abnormal and leads to cell death [41]. This first mechanism of action involving histone acetylation inhibition is considered as one of the most important epigenetic modifications acting on signal transduction pathways involved in cancer development $[42,43]$. When the cells are in the steady-state conditions, the core $\mathrm{H} 3$ and $\mathrm{H} 4$ histones are mostly deacetylated, as a repressed state. When cells were treated with peptide lunasin and well-known deacetylase inhibitor sodium butyrate, histone acetylation was inhibited in C3H10T1/2 fibroblasts and breast cancer MCF-7 cells [44-46]. Furthermore, lunasin has been demonstrated to compete with different histone acetyltransferase enzymes (HATs), such as yGCN5 and PCAF, inhibiting the acetylation and repressing the cell cycle progression [46-49]. Recently, we have reported that lunasin is a potent inhibitor of histones $\mathrm{H} 3$ and $\mathrm{H} 4$ histone acetylation $[49,50]$. Lunasin's inhibitory activity was found to be higher than that demonstrated by other compounds, such as anacardic acid and curcumin, which chemopreventive properties have been already reported [51-53]. Studies focused on elucidating lunasin's structureactivity relationship establish that lunasin's sequence is essential for inhibiting $\mathrm{H} 4$ acetylation whereas poly-D sequence is the main active sequence responsible for $\mathrm{H} 3$ acetylation inhibition [50].

Lunasin has been demonstrated that it causes cytotoxicity in four different human colon cancer cell lines, KM12L4, RKO, HCT-116, and HT-29 cell, with IC50 values of $13.0 \mu \mathrm{M}, 21.6 \mu \mathrm{M}, 26.3 \mu \mathrm{M}$ and $61.7 \mu \mathrm{M}$, respectively [54]. These values suggest that lunasin is most potent killing the highly metastatic KM12L4 colon cancer cells than any other colon cell lines used in this study. Moreover, lunasin was capable to provoke cytotoxic effects on the oxaliplatin-resistant variants of this colon cancer cells [55]. Studies on mechanism of action of this peptide have revealed that lunasin causes arrest of cell cycle in G2/M phase and induction of the mitochondrial pathway of apoptosis. The cell cycle arrest was attributed with concomitant increase in the expression of the p21 protein in HT-29 colon cancer cells, while both p21 and p27 protein expressions were up-regulated by lunasin treatment in KM12L4 colon cancer cells $[54,56]$. Moreover, treatment with lunasin decreased the ratio of $\mathrm{Bcl}-2$ : Bax by up-regulating the expression of the proapoptotic Bax and downregulating the expression of the anti-apoptotic Bcl-2, also increasing the activity of caspase-3 [55]. This might be attributed to the increase in the expression of the pro-apoptotic form of clusterin which is positively affected by the increase p 21 expression in cell nucleus. Treatment of lunasin causes translocation of Bax into the mitochondrial membrane resulting in the release of cytochrome $\mathrm{c}$ and the increase of the expression of cytosolic cytochrome $\mathrm{c}$ in KM12L4 cells. It was also demonstrated that treatment with lunasin provokes an increase in the activity of caspase- 9 and caspase- 3 in both HT-29 and KM12L4 cells [56]. Furthermore, lunasin has been showed to modify the expression of human extracellular matrix and adhesion genes [56]. The Arg-Gly-Asp motif present in the lunasin structure is a recognition site for integrin receptors present in the extracellular matrix (ECM). Integrins are heterodimeric receptors associated with cell adhesion, and cancer metastasis [57]. Treatment of KM12L4 cells with lunasin resulted in the modification on the expression of 62 genes associated with ECM and cell adhesion [56]. These authors also reported that lunasin downregulated the gene expression of collagen type VII $\alpha 1$, integrin $\beta 2$, matrix metalloproteinase 10 , selectin $\mathrm{E}$ and integrin $\alpha 5$ by 10.1-, 8.2-, 7.7-, 6.5- and 5.0-fold, respectively, compared to the untreated CRC cells. On the other hand, the expression of collagen 
type XIV $\alpha 1$ was up-regulated on lunasin treatment by 11.6 -fold. These results suggest a potential role of peptide lunasin as an agent to combat metastatic colon cancer particularly in cases where resistance to chemotherapy develops.

In another study, colon cancer liver metastasis is a widely used model to study the effects of different markers and chemotherapy on colon cancer metastasis. Recently, Dia and Gonzalez de Mejia have reported that lunasin acts as chemopreventive agent against this type of metastasis using colon cancer KM12L4 cells directly injected into the spleen of athymic mice [54]. Lunasin administered at concentration of $4 \mathrm{mg} / \mathrm{kg}$ body weight resulted in a significant inhibition of liver metastasis of colon cancer cells, potentially because of its binding to $\alpha 5 \mathrm{~b} 1$ integrin and subsequent suppression of FAK/ERK/NF-kB signaling. Lunasin was also capable to potentiate the effect of oxaliplatin in preventing the outgrowth of metastasis. Moreover, lunasin potentiated the effect of oxaliplatin in modifying expression of proteins involved in apoptosis and metastasis including Bax, Bcl-2, IKK- $\alpha$ and p-p65 [50]. These results suggest that lunasin can be used as a potential integrin antagonist thereby preventing the attachment and extravasation of colon cancer cells leading to its anti-metastatic effect. These results open a new vision about the lunasin used in metastasis that might benefit to prolong the survival of mice with metastatic colon cancer [58].

Effect of giving seed and SE for dysplasia index as shown in Figs. 4 and 6. In Fig. 4 with ANOVA analysis shows that GE and SE decreased dysplasia $(p=0.024)$. GE $(200 \mathrm{mg} / \mathrm{kg})$ has the highest impact level of dysplasia $(\mathrm{p}=0.002)$ and SE $(200 \mathrm{mg} / \mathrm{kg})$ has the second impact level of dysplasia $(\mathrm{p}=0.003)$. In Fig. 6 , it shows that hematoxylin-eosin staining with dysplasia.

In another study, the effect of dietary supplementation with isoflavone-free soy protein concentrate (SPC) on colon inflammation and carcinogenesis in male, CF-1 mice was investigated in one 10-week and one 20-week study. In both studies, following one-week pretreatment with SPC or casein as the sole source of protein (19\% kcal), mice were injected with the colon carcinogen (AOM, $10 \mathrm{mg} / \mathrm{kg}$ body wt). One week later, mice received (DSS, $1.5 \% \mathrm{w} / \mathrm{v}$ ) as their sole drinking fluid for one week to induce colon-specific inflammation. On days 3 and 7 , and weeks 7 and 20 (second study only) after DSS treatment, mice were euthanized and the colons were examined for markers of inflammation and carcinogenesis. All samples were scored using the inflammation index, which measures inflammation area, severity, ulceration and hyperplasia and dysplasia. In both studies, trends in these measures appeared to be highly dependent on sacrifice time-point. With the data from both studies combined, mean polyp multiplicity was significantly reduced in mice fed SPC at week 7 and for the study overall $(\mathrm{p}<0.001$ and $\mathrm{p}<0.01$, respectively). Hyperplasia and dysplasia, inflammation area and total inflammation index score were significantly decreased in the SPC group compared to the control at week 7 ( $<<0.10, \mathrm{p}<0.10$ and $\mathrm{p}<0.05$, respectively). At 20 weeks, mice in both the control and SPCtreated groups showed colon tumors. The trend toward reduced tumor burden and multiplicity in mice fed the SPC diet was observed, but the effect was not statistically significant [59].

\section{CONCLUSION}

In conclusion, we have shown that GE and SE have beneficial actions in an experimental model of colon cancer. Both of them inhibition of colon carcinogenesis with increased level of apoptosis and decrease level of dysplasia.

\section{ACKNOWLEDGMENTS}

Authors thank Directorate of research and community service (DRPM) University of Indonesia for PITTA research grant.

\section{REFERENCES}

1. Ferlay J, Soerjomataram I, Ervik M, Dikshit R, Eser S, Mathers C, et al. GLOBOCAN 2012 v1.1, Cancer Incidence and Mortality Worldwide:
IARC Cancerbase No. 11. Lyon, France: International Agency for Research on Cancer; 2014. Available from: http://www.globocan.iarc. fr. [Last accessed on 2015 Jan 16].

2. Theodoratou E, Farrington SM, Tenesa A, McNeill G, Cetnarskyj R, Korakakis E, et al. Associations between dietary and lifestyle risk factors and colorectal cancer in the Scottish population. Eur J Cancer Prev 2014;23(1):8-17.

3. Kriza C, Emmert $M$, Wahlster P, Niederländer C, KolominskyRabas P. Cost of illness in colorectal cancer: An international review. Pharmacoeconomics 2013;31(7):577-88

4. Derry MM, Raina K, Agarwal C, Agarwal R. Identifying molecular targets of lifestyle modifications in colon cancer prevention. Front Oncol 2013;3:119.

5. Ebos JM, Kerbel RS. Antiangiogenic therapy: Impact on invasion, disease progression, and metastasis. Nat Rev Clin Oncol 2011;8(4):210-21.

6. Franceschi S, Wild CP. Meeting the global demands of epidemiologic transition - The indispensable role of cancer prevention. Mol Oncol 2013;7(1):1-13.

7. Coward L, Barnes N, Setchell K, Barnes S. Genistein, daidzein, and their beta-glycoside conjugates: Antitumor isoflavones in soybean food from American and Asian diets. J Agric Food Chem 1993;41(11):1961-7.

8. Wang H, Murphy P. Isoflavone content in commercial soybean foods. J Agric Food Chem 1994;42(8):1666-73.

9. Fournier DB, Erdman JW Jr, Gordon GB. Soy, its components, and cancer prevention: A review of the in vitro, animal, and human data. Cancer Epidemiol Biomarkers Prev 1998;7(11):1055-65.

10. Anderson JW, Smith BM, Washnock CS. Cardiovascular and renal benefits of dry bean and soybean intake. Am J Clin Nutr 1999;70 3 Suppl:464S-74.

11. Swanson CA, Mao BL, Li JY, Lubin JH, Yao SX, Wang JZ, et al. Dietary determinants of lung-cancer risk: Results from a case-control study in Yunnan Province, China. Int J Cancer 1992;50(6):876-80.

12. $\mathrm{Wu} \mathrm{AH}$, Ziegler RG, Horn-Ross PL, Nomura AM, West DW, Kolonel LN, et al. Tofu and risk of breast cancer in Asian-Americans. Cancer Epidemiol Biomarkers Prev 1996;5(11):901-6.

13. Goodman MT, Wilkens LR, Hankin JH, Lyu LC, Wu AH, Kolonel LN. Association of soy and fiber consumption with the risk of endometrial cancer. Am J Epidemiol 1997;146(4):294-306.

14. Jacobsen BK, Knutsen SF, Fraser GE. Does high soy milk intake reduce prostate cancer incidence? The Adventist Health Study (United States). Cancer Causes Control 1998;9(6):553-7.

15. Zheng W, Dai Q, Custer LJ, Shu XO, Wen WQ, Jin F, et al. Urinary excretion of isoflavonoids and the risk of breast cancer. Cancer Epidemiol Biomarkers Prev 1999;8(1):35-40.

16. Kolonel LN, Hankin JH, Whittemore AS, Wu AH, Gallagher RP, Wilkens LR, et al. Vegetables, fruits, legumes and prostate cancer: A multiethnic case-control study. Cancer Epidemiol Biomarkers Prev 2000;9(8):795-804.

17. Sun CL, Yuan JM, Arakawa K, Low SH, Lee HP, Yu MC. Dietary soy and increased risk of bladder cancer: The Singapore Chinese health study. Cancer Epidemiol Biomarkers Prev 2002;11(12):1674-7.

18. Messina M, Flickinger B. Hypothesized anticancer effects of soy: Evidence points to isoflavones as the primary anticarcinogens. Pharm Biol 2002;40(1):S6-23

19. de Lumen BO. Lunasin: A cancer-preventive soy peptide. Nutr Rev 2005;63(1):16-21

20. Lam Y, Galvez A, de Lumen BO. Lunasin suppresses E1A-mediated transformation of mammalian cells but does not inhibit growth of immortalized and established cancer cell lines. Nutr Cancer 2003;47(1):88-94

21. Jeong HJ, Lam Y, de Lumen BO. Barley lunasin suppresses ras-induced colony formation and inhibits core histone acetylation in mammalian cells. J Agric Food Chem 2002;50(1):5903-8.

22. Galvez AF, Chen N, Macasieb J, de Lumen BO. Chemopreventive property of a soybean peptide (lunasin) that binds to deacetylated histones and inhibits acetylation. Cancer Res 2001;61(20):7473-8.

23. Shogren-Knaak M, Ishii H, Sun JM, Pazin MJ, Davie JR, Peterson CL. Histone H4-K16 acetylation controls chromatin structure and protein interactions. Science 2006;311(5762):844-7.

24. Yasui W, Oue N, Ono S, Mitani Y, Ito R, Nakayama H. Histone acetylation and gastrointestinal carcinogenesis. Ann N Y Acad Sci 2003;983:220-31.

25. Galvez AF, de Lumen BO. A soybean cDNA encoding a chromatinbinding peptide inhibits mitosis of mammalian cells. Nat Biotechnol 1999;17(5):495-500.

26. Dia VP, Wang W, Oh VL, de Lumen BO, de Mejia EG. Isolation, 
purification and characterisation of lunasin from defatted soybean flour and in vitro evaluation of its anti-inflammatory activity. Food Chem 2009;114(1):108-15.

27. Seber LE, Barnett BW, McConnell EJ, Hume SD, Cai J, Boles K, et al. Scalable purification and characterization of the anticancer lunasin peptide from soybean. PLoS One 2012;7(4):e35409.

28. Kusmardi, Priosoeryanto BP, Herlina E, Cornain S. Activity of fish oil inhibbtion preneoplasia colon of mice induced azoxymethan adn dextran sodium sulfate. Indonesian Journal of Pharmaceutical Sciences 2014;2(2):151-61

29. Banaszkiewicz T. Poultry Feeding Standards. Jablonna, Warszawa, Poland: The Kielanowski Institute of Animal Physiology and Nutrition, Polish Academy of Sciences; 2005.

30. Bhathena SJ, Velasquez MT. Beneficial role of dietary phytoestrogens in obesity and diabetes. Am J Clin Nutr 2002;76(6):1191-201.

31. Li FN, Li LL, Yang HS, Yuan XX, Zhang B, Geng MM, et al. Regulation of soy isoflavones on weight gain and fat percentage: Evaluation in a Chinese Guangxi minipig model. Animal 2011;5(12):1903-8.

32. Algra AM, Rothwell PM. Effects of regular aspirin on long-term cancer incidence and metastasis: A systematic comparison of evidence from observational studies versus randomised trials. Lancet Oncol 2012;13(5):518-27.

33. Singh Ranger G. The role of aspirin in colorectal cancer chemoprevention. Crit Rev Oncol Hematol 2016;104:87-90.

34. Narayanan BL, Venkatesan N, Subburaju T, Fathah A. Chemopreventive role of combination of etoricoxib and atrovastatin on colon cancer induced by 1,2-dimethyl hydrazine on rats. Int J Pharm Pharm Sci 2015;7(9):299-303.

35. Patrignani P, Capone ML, Tacconelli S. Clinical pharmacology of etoricoxib: Anovel selective COX2 inhibitor. Expert Opin Pharmacother 2003;4(2):265-84

36. Tanaka T. Development of an inflammation-associated colorectal cancer model and its application for research on carcinogenesis and chemoprevention. Int J Inflam 2012;2012:658786.

37. Garcia-Albeniz X, Chan AT. Aspirin for the prevention of colorectal cancer. Best Pract Res Clin Gastroenterol 2011;25(4-5):461-72.

38. Messina MJ. Legumes and soybeans: Overview of their nutritional profiles and health effects. Am J Clin Nutr 1999;70 3 Suppl:439S-50.

39. Soni N, Pardasani KR, Mujwar S. Insilico analysis of dietary agents as anticancer inhibitors of insulin like growth factor 1 receptor (1GF1R). Int J Pharm Pharm Sci 2015;7(9):191-6.

40. Mahmoud AM, Yang W, Bosland MC. Soy isoflavones and prostate cancer: A review of molecular mechanisms. J Steroid Biochem Mol Biol 2014; 140:116-32.

41. de Lumen BO. Lunasin: A cancer-preventive soy peptide. Nutr Rev 2005;63(1):16-21.

42. Dwarakanath BS, Verma A, Bhatt AN, Parmar VS, Raj HG. Targeting protein acetylation for improving cancer therapy. Indian J Med Res 2008;128(1):13-21.

43. Dalvai M, Bystricky K. The role of histone modifications and variants in regulating gene expression in breast cancer. J Mammary Gland Biol Neoplasia 2010;15(1):19-33.

44. Dia VP, Gonzalez de Mejia E. Lunasin potentiates the effect of oxaliplatin preventing outgrowth of colon cancer metastasis, binds to a5ß1 integrin and suppresses FAK/ERK/NF-?B signaling. Cancer Lett 2011;313(2):167-80.

45. Galvez AF, Chen N, Macasieb J, de Lumen BO. Chemopreventive property of a soybean peptide (lunasin) that binds to deacetylated histones and inhibits acetylation. Cancer Res 2001;61(20):7473-8.

46. Jeong HJ, Park JH, Lam Y, de Lumen BO. Characterization of lunasin isolated from soybean. J Agric Food Chem 2003;51(27):7901-6.

47. Jeong HJ, Lam Y, de Lumen BO. Barley lunasin suppresses ras-induced colony formation and inhibits core histone acetylation in mammalian cells. J Agric Food Chem 2002;50(21):5903-8

48. Jeong HJ, Jeong JB, Kim DS, Park JH, Lee JB, Kweon DH, et al. The cancer preventive peptide lunasin from wheat inhibits core histone acetylation. Cancer Lett 2007;255(1):42-8

49. Jeong JB, Jeong HJ, Park JH, Lee SH, Lee JR, Lee HK, et al. Cancerpreventive peptide lunasin from Solanum nigrum L. inhibits acetylation of core histones $\mathrm{H} 3$ and $\mathrm{H} 4$ and phosphorylation of retinoblastoma protein (Rb). J Agric Food Chem 2007;55(26):10707-13.

50. Hernández-Ledesma B, Hsieh $\mathrm{CC}$, de Lumen BO. Relationship between lunasin's sequence and its inhibitory activity of histones H3 and H4 acetylation. Mol Nutr Food Res 2011;55(7):989-98.

51. Balasubramanyam K, Swaminathan V, Ranganathan A, Kundu TK. Small molecule modulators of histone acetyltransferase p300. J Biol Chem 2003;278(21):19134-40.

52. Balasubramanyam K, Altaf M, Varier RA, Swaminathan V, Ravindran A, Sadhale PP, et al. Polyisoprenylated benzophenone, garcinol, a natural histone acetyltransferase inhibitor, represses chromatin transcription and alters global gene expression. J Biol Chem 2004;279(32):33716-26.

53. Balasubramanyam K, Varier RA, Altaf M, Swaminathan V, Siddappa NB, Ranga U, Kundu TK. Curcumin, a novel p300/CREB-binding proteinspecific inhibitor of acetyltransferase, represses the acetylation of histone/nonhistone proteins and histone acetyl transferase dependent chromatin transcription. J Biol Chem 2004;279(49):51163-71.

54. Dia VP, Gonzalez de Mejia E. Lunasin induces apoptosis and modifies the expression of genes associated with extracellular matrix and cell adhesion in human metastatic colon cancer cells. Mol Nutr Food Res 2011;55(4):623-34.

55. Dia VP, Gonzalez de Mejia E. Lunasin potentiates the effect of oxaliplatin preventing outgrowth of colon cancer metastasis, binds to a5ß1 integrin and suppresses FAK/ERK/NF-?B signaling. Cancer Lett 2011;313(2):167-80.

56. Dia VP, Mejia EG. Lunasin promotes apoptosis in human colon cancer cells by mitochondrial pathway activation and induction of nuclear clusterin expression. Cancer Lett 2010;295(1):44-53.

57. Dittmar T, Heyder C, Gloria-Maercker E, Hatzmann W, Zänker KS. Adhesion molecules and chemokines: The navigation system for circulating tumor (stem) cells to metastasize in an organ-specific manner. Clin Exp Metastasis 2008;25(1):11-32.

58. Dia VP, de Mejia EG. Potential of lunasin orally-administered in comparison to intraperitoneal injection to inhibit colon cancer metastasis in vivo. J Cancer Ther 2013;4(6B):34-43.

59. Brownschidle AM. The effect of soy protein on colon carsinogenesis in vitro and in vivo. Thesis in Food Science, The Pennsylvania State University; 2011. 